Neurotoxic Effects of Subchronic Intratracheal Mn Nanoparticle Exposure Alone and in Combination with Other Welding Fume Metals in Rats

Short title:

Neurotoxicity of Welding Fume Nanoparticles

Authors:

Zsuzsanna Máté ${ }^{*}$, Edina Horváth ${ }^{1}$, András Papp $^{1}$, Krisztina Kovács $^{2}$, Etelka Tombácz ${ }^{2}$, Dániel Nesztor ${ }^{2}$, Tamás Szabó ${ }^{2}$, Andrea Szabó ${ }^{1}$, Edit Paulik ${ }^{1}$

${ }^{1}$ Department of Public Health, Faculty of Medicine, University of Szeged, Hungary H-6720 Szeged, Dóm tér 10., Hungary

Phone: +36-62-545-119, Fax: +36-62-545-120

E-mail: office.puhe@med.u-szeged.hu

${ }^{2}$ Department of Physical Chemistry and Materials Science, Faculty of Science and Informatics, University of Szeged, Hungary

H-6720 Szeged, Aradi vértanúk tere 1.

Phone: +36-62-544-212, Fax: +36-62-544-049

E-mail: e.tombacz@chem.u-szeged.hu

*Corresponding author: Zsuzsanna Máté

E-mail:mate.zsuzsanna@med.u-szeged.hu 


\title{
Neurotoxic Effects of Subchronic Intratracheal Mn Nanoparticle Exposure Alone and in Combination with Other Welding Fume Metals in Rats
}

\begin{abstract}
Manganese (Mn) is a toxic heavy metal exposing workers in various occupational settings and causing, among others, nervous system damage. Metal fumes of welding, a typical source of Mn exposure, contain a complex mixture of metal oxides partly in nanoparticle form. As toxic effects of complex substances cannot be sufficiently understood by examining its components separately, general toxicity and functional neurotoxicity of a main pathogenic welding fume metal, $\mathrm{Mn}$, was examined alone and combined with iron $(\mathrm{Fe})$ and chromium $(\mathrm{Cr})$, also frequently found in fumes. Oxide nanoparticles of $\mathrm{Mn}, \mathrm{Mn}+\mathrm{Fe}, \mathrm{Mn}+\mathrm{Cr}$ and the triple combination were applied, in aqueous suspension, to the trachea of young adult Wistar rats for 4 weeks. The decrease of body weight gain during treatment, caused by Mn, was counteracted by $\mathrm{Fe}$, but not $\mathrm{Cr}$. At the end of treatment, spontaneous and evoked cortical electrical activity was recorded. Mn caused a shift to higher frequencies, and lengthened evoked potential latency, which were also strongly diminished by co-application of Fe only. The interaction of the metals seen in body weight gain and cortical activity were not related to the measured blood and brain metal levels. Fe might have initiated protective, e. g. antioxidant, mechanisms with a more general effect.
\end{abstract}

Keywords: nanoparticle, neurotoxicity, welding fume, rat, intratracheal 


\section{Introduction}

$\mathrm{Mn}$ is an essential micronutrient for humans and for all living organisms, required, among others, for the development and the normal function of the central nervous system (CNS; Elder et al. 2006). When overdosed, however, first of all for longer periods, it acts as a neurotoxicant. The human disease caused by chronic exposure to higher doses, called manganism (Saric et al. 1977; Calne et al. 1994) leads to a Parkinson-like end stage.

Electrophysiological signs of CNS damage, seen after welding-related occupational Mn exposure, include myoclonus in welders (Ono et al. 2002) as well as electroencephalogram (EEG) and evoked potential (EP) alterations (Sinczuk-Walczak et al. 2001).

Oxidative stress is apparently a major feature of Mn neurotoxicity. This includes mitochondrial toxicity (inhibition of complex II and III: Malecki 2001; Zhang et al. 2003), oxidation of dopamine and other catecholamines ( $\mathrm{Mn}$ is accumulated in dopamine-rich brain regions, especially in the basal ganglia: Erikson and Aschner 2003) and decreased activity of Mn-SOD and glutathion peroxidase (HaMai and Bondy 2004). In rats, increased lipid peroxidation was found after one month of oral Mn exposure, and was linked to decreased motility (Avila et al. 2008).

Previous own studies on the neurotoxicity of $\mathrm{Mn}$ revealed, as the main electrophysiological alteration in rats, a latency lengthening of cortical sensory EPs, observed after several weeks of $\mathrm{Mn}$ exposure by the oral route (dissolved $\mathrm{MnCl}_{2}$ : Vezér et al. 2005) or by intratracheal application of dissolved (Máté et al. 2011) or nanoparticulate $\mathrm{Mn}\left(\mathrm{MnO}_{2}\right.$ nanoparticles (NPs): Oszlánczi et al. 2010). Parallel shift of the spontaneous cortical activity to higher frequencies was also observed. It was also found that green tea, a known powerful antioxidant (Guo et al. 1996; Frei and Higdon 2003) could diminish these neuro-functional alterations in rats receiving intratracheal $\mathrm{MnO}_{2} \mathrm{NP}$ exposure (Sárközi et al. 2017).

Human consequences of long-term Mn exposure are, as outlined above, seen mostly in workplace settings. Several processes of metal industry result in generation of metal dusts and fumes, with welding as one of the major sources. Welding fume - a typical industrial aerosol - is a complex mixture containing solid particles of metal oxides, a significant part of which has a diameter below $100 \mathrm{~nm}$, i.e. they are NPs (Antonini et al. 2010). Such particles show peculiar physicochemical, and hence, biological and health-related properties, the most important being large specific surface area and surface reactivity. Surface reactions generate reactive oxygen species (ROS) and may activate various cell surface receptors; at high particle number concentration, this leads to great biological and chemical activity (Oberdörster et al. 2005). NPs inhaled from a polluted (e.g. workplace) atmosphere are typically deposited in the nasopharynx or the alveoli (ICRP 1994) but cause adverse health effects also in extrapulmonary organs, resulting from size-dependent high mobility within the organism (Oberdörster et al. 2005). Extrapulmonary effects of NPs depend on several factors including particle composition and solubility, particle or aggregate size, site of deposition, and the integrity of the alveolar epithelial lining (Elder et al. 2006). In rats, NPs of various compositions have been detected in the brain after application through the airways (Kreyling et al. 2006). Access of NPs to distant body parts after inhalational exposure has been detected 
also in humans (Theegarten et al. 2010). In welders and other metalworkers, routinely exposed to high concentrations of metal fumes, health problems of the nervous system have been described (Bowler et al. 2006). NPs in the fumes represent one of the damaging factors (Antonini et al. 2003) and their chemical composition, beside size and surface reactivity, is of importance. The most common metal elements in the metal parts and welding rods that welders are primarily exposed to by metal fume inhalation are $\mathrm{Fe}, \mathrm{Mn}$ and $\mathrm{Cr}$, followed by nickel, silicon, aluminium etc. (Jenkins 2003).

In the victims of welding-related manganism (Bowler et al. 2006), enhanced magnetic resonance imaging (MRI) signal of the basal ganglia, due to deposition of Mn, was found (Chang et al. 2010), indicating access of the metal content of the inhaled fumes to the CNS. After exposing rats to stainless steel welding fumes (containing $\mathrm{Mn}, \mathrm{Cr}$ and $\mathrm{Fe}$ as well), Park et al. (2007) described increased levels of $\mathrm{Mn}$ in different brain regions, underlining the possible transport of $\mathrm{Mn}$ to the brain through the lung/blood circulation.

The two other major metals in welding fumes, $\mathrm{Fe}$ and $\mathrm{Cr}$ (the role of which in neurotoxicity is much less known), are capable of redox cycling similarly to $\mathrm{Mn}$, and contribute this way to oxidative stress (Valko et al. 2005). In case of Fe overload, Fe can deposit in certain mitochondria rich organs, and causes disruption of the mitochondrial energy production by decreasing enzyme activity (Bacon et al. 1993), resulting in generation of ROS. The role of Fe deposited in the basal ganglia in Parkinson's or Alzheimer's disease, via a mechanism involving oxidative stress, has also been reported (Sayre et al. 1999).

Occupational exposure to $\mathrm{Cr}$ compounds and their respiratory effects have been described several times (Derelanko et al. 1999), but information about the neurological effects in humans or animals is scarce. In 1941, Lieberman described workers with symptoms of dizziness, headache and weakness after excessive inhalation of $\mathrm{Cr}$ aerosols. In rats treated with sodium chromate, decreased motility was observed (Diaz-Mayans et al. 1986), and Repetto et al. (1996) reported $\mathrm{Cr}^{3+}$ toxicity on a neuroblastoma cell line in vitro. $\mathrm{Cr}_{2} \mathrm{O}_{3}$ is a trivalent $\mathrm{Cr}$ oxide compound, often generated in industrial process. Horie et al. (2013) reported that cytotoxicity of nanoparticulate $(60 \mathrm{~nm}) \mathrm{Cr}_{2} \mathrm{O}_{3}$ was higher compared to fine particles, and that $\mathrm{Cr}_{2} \mathrm{O}_{3}$ NPs reduced the mitochondrial activity and released hexavalent $\mathrm{Cr}$ in the medium. The substance used in the present work, nanoparticulate $\mathrm{Cr}(\mathrm{OH})_{3}$, is the hydrated form of $\mathrm{Cr}_{2} \mathrm{O}_{3}$.

Welding as a job affects many people, possibly inducing negative health effects including CNS damage, and these effects of welding fumes cannot be assessed based only on individual toxicity data of the components. The aim of the present study was thus to investigate the general toxicological and CNS electrophysiological effects of nanoparticulate $\mathrm{Mn}$, a major component of welding fumes, alone and in combination with $\mathrm{Fe}$ and/or $\mathrm{Cr}$, in a subacute rat model using intratracheal application.

\section{Materials and Methods}

\section{Experimental Animals and Substances}

Fifty-four 9 weeks old male Wistar rats (260-280 g body weight at start) were obtained from 
the university's breeding center. The animals were housed in standard polypropylene cages with a stainless steel top grill, with up to four rats in one cage, under GLP-equivalent conditions $\left(22 \pm 1{ }^{\circ} \mathrm{C}, 30-60 \%\right.$ relative humidity, 12-h light/dark cycle with light on at 06:00), and had free access to tap water and standard rodent pellet. The rats were randomly divided into 7 treatment groups (as shown in Table 1), and were allowed one week for acclimatization before the treatment period.

The rats were exposed to the heavy metal containing NPs by intratracheal instillation in daily doses of $2 \mathrm{mg} / \mathrm{kg}$ b. w. (with $\mathrm{MnO}_{2} \mathrm{NPs}$, also in $4 \mathrm{mg} / \mathrm{kg}$ b. w. daily dose). Calculated with the respiratory minute volume of Wistar rats in our age range (based on physiological data by Filho et al. 2014), $0.5 \mathrm{~m}^{3} / \mathrm{kg}$ b. w. ventilation volume is supposed for a rat for 8 hours. Based on this data, the intratracheal NP dose of $2 \mathrm{mg} / \mathrm{kg}$ corresponds to $4 \mathrm{mg} / \mathrm{m}^{3}$ (and intratracheal dose of $4 \mathrm{mg} / \mathrm{kg}$ to $8 \mathrm{mg} / \mathrm{m}^{3}$ ) atmospheric concentration in continuous 8 -hour (occupational) exposure. The American Conference of Governmental Industrial Hygienists' threshold limit value-time weighted average (ACGIH TLV-TWA) for manganese fume (as $\mathrm{Mn}$ ) is $0.2 \mathrm{mg} / \mathrm{m}^{3}$ (ACGIH, 2012); for iron oxide, it is $5.0 \mathrm{mg} / \mathrm{m}^{3}$ (ACGIH, 2006); and for chromium (III), $0.5 \mathrm{mg} / \mathrm{m}^{3}$ (ACGIH, 1991). In a survey published by Korczynski (2000), the Mn levels in workplace air polluted by welding fumes ranged from 0.01 to $4.93 \mathrm{mg} / \mathrm{m}^{3}$, while iron ranged from 0.04 to $16.29 \mathrm{mg} / \mathrm{m}^{3}$. The applied doses thus relate to possible daily occupational exposures, and can be compared to the TLV-TWA values, concentrations to which workers are exposed on the basis of a $8 \mathrm{~h} /$ day, $40 \mathrm{~h} /$ week work schedule, without adverse health effects.

Intratracheal instillation was carried out in brief diethyl ether anesthesia, based on the method of Oka et al. (2006). The anaesthetized rat was put on a tilted board (60 to horizontal) hanging with the upper incisors in a wire loop, and the larynx was illuminated transdermally by means of a fiber optic light guide placed against the animal's neck. The larynx and trachea was visualized using a custom-made laryngoscope to gain access to the glottis. The tongue was pulled forward with a pair of non-traumatic forceps, and the suspension of the NPs (or the vehicle) was instilled into the trachea by means of a $1 \mathrm{ml}$ syringe connected to a thin plastic tube (1.2 mm OD) inserted between the vocal chords. Instillation volume was $1 \mathrm{ml} / \mathrm{kg} \mathrm{b}$. w. Treatment was performed once a day, 5 times per week, for 4 weeks (for daily doses, see Table 1). Our previous experience (Horváth et al. 2012) showed that the nervous system effects of NP form of Mn (and other metals) would develop in 4 weeks, but animal loss would be minimal.

In case of the combination groups (see Table 1), $\mathrm{Fe}_{3} \mathrm{O}_{4}$ and $\mathrm{MnO}_{2} \mathrm{NPs}_{\text {s were both }}$ suspended in the polyacrylic acid (PAA) medium and could be administered together (for preparation of the nanosuspensions, see below). However, $\mathrm{Cr}(\mathrm{OH})_{3} \mathrm{NPs}$ were suspended in normal saline and had to be instilled separately. Administration of NPs in different vehicles (combinations containing $\mathrm{Cr}: M C$ and $M F C$ ) was separated in time by 4 hours in order to decrease burden put on the lungs by the instillation (that is, to avoid the administration of double volume). An untreated control (Cont) and a vehicle control (VC) group was also used because of the expectable own effects of the treatment procedure. The $V C$ group was treated with PAA and then normal saline (with 4-hour delay), using the same regime as with the NPtreated groups. 
[Table 1 near here]

\section{Synthesis and Characterization of the Nanoparticles}

The NPs of $\mathrm{MnO}_{2}, \mathrm{Fe}_{3} \mathrm{O}_{4}$ and $\mathrm{Cr}(\mathrm{OH})_{3}$ were synthesized at the Department of Physical Chemistry and Materials Science, University of Szeged, Faculty of Science and Informatics.

For $\mathrm{MnO}_{2}$ NPs, an aqueous alkaline medium containing PAA (MW: 5000) and ethanol was prepared and stoichiometric amount of $\mathrm{KMnO}_{4}$ solution was dripped into it under stirring. A sol containing $\mathrm{MnO}_{2} \mathrm{NPs}$ was generated, the concentration and $\mathrm{pH}$ of which was adjusted as desired with high purity water and $\mathrm{HCl}$. For vehicle control, the starting medium was completed with $\mathrm{KOH}$ and $\mathrm{NaOH}$, and $\mathrm{pH}$ was set to ca. 7. The method of preparation was based on the United States Patent 5268408 (Milner 1993).

$\mathrm{Fe}_{3} \mathrm{O}_{4}$ NPs were generated in a concentrated solution of ferrous and ferric chloride by adding $\mathrm{NaOH}$ in $10 \%$ excess slowly, then suddenly under vigorous stirring. The resulting black suspension was washed from residual alkali, then acidified strongly to induce peptization. $\mathrm{Fe}_{3} \mathrm{O}_{4}$ NPs were stabilized with PAA, and $\mathrm{NaCl}, \mathrm{HCl}$ and $\mathrm{NaOH}$ solutions were used to adjust $\mathrm{pH}$ 6.5. The procedure, characterization and stability of the $\mathrm{Fe}_{3} \mathrm{O}_{4} \mathrm{NPs}$ were described in details by Hajdú et al. (2012).

$\mathrm{Cr}(\mathrm{OH})_{3}$ NPs were also generated by alkali treatment (based on the method described by Demchak and Matijević et al. 1969), this time in a $\mathrm{CrCl}_{3}$ solution at boiling temperature. After cooling, $\mathrm{pH}$ was set to 4.11, and the solution was reheated for aging the precipitate 6 hours long. The precipitate was repeatedly washed by centrifuging and resuspending in ultrapure (UP) water until peptization took place. For administration, $\mathrm{pH}$ was set to 6.0 and concentration was adjusted. Each nanosuspension was freshly prepared each Monday, and was sonicated once per week in an ultrasonic bath to maintain its stability.

The NPs were characterized using transmission electron microscopy (TEM) and dynamic light scattering (DLS). For TEM imaging, highly diluted aqueous NP suspensions were deposited on carbon-coated copper grids (EMS CF200-Cu) and were air-dried. TEM micrographs were taken using a JEOL JEM 1400+ transmission electron microscope with 80 $\mathrm{kV}$ accelerating voltage. Size distribution was determined by evaluating approximately 100 particles using the JMicroVision 1.2.7 software (Roduit [date unknown]).

DLS measurements were performed using a NanoZS apparatus (Malvern, UK) with the laser beam $\lambda=633 \mathrm{~nm}$ produced by a He-Ne laser, operating in back-scattering mode at an angle of $173^{\circ}$. The measuring cell (DTS 1060) was used to determine both hydrodynamic size distribution and charge state of nanoparticles dispersed in aqueous media. The measurements were performed at $25 \pm 0.1^{\circ} \mathrm{C}$. Stock suspensions were diluted by UP water obtained from Zeener water purification system (HumanCorp, Korea), then their $\mathrm{pH}$ was adjusted to ca. 6.5 by addition of dilute $\mathrm{NaOH} / \mathrm{HCl}$. Solid content of the samples was about $0.1 \mathrm{mg} / \mathrm{ml}$ and their ionic strength was low $(0.05$ to $1.6 \mathrm{mmol} / \mathrm{l})$. Size determination was run first, then the electrophoretic mobility of NPs was measured. Size data were calculated from the fitted correlation functions assuming that translational diffusion was the dominant dynamics and the Stokes-Einstein equation could be used. The instrument was calibrated by measuring the zeta potential of a zeta-standard $(55 \pm 5 \mathrm{mV})$ supplied by Malvern, which 
reports an accuracy of $\pm 5 \mathrm{mV}$. The Smoluchowski equation was applied to convert the electrophoretic mobility to zeta potential values.

\section{General Toxicological Investigations}

The body weight of the animals was measured every day during the experiment. From these data, the exact daily NP doses were calculated, and weekly body weight gain was determined, separately for each rat. Body weight gain (the difference of body weight on Friday of the given week and Friday of the pre-treatment week calculated in percentages) was averaged group by group, and used as an indicator of general toxicity. Following electrophysiological recording (at the end of the 4-week treatment period; see below), the animals were sacrificed by an overdose of urethane and were dissected. Blood was collected from the abdominal vein, brain and lungs were removed, and the samples were stored at $-22{ }^{\circ} \mathrm{C}$ in microcentrifugation vials and polyethylene self-sealing bags, respectively.

Tissue levels of Mn, Fe and $\mathrm{Cr}$ (possibly indicating the presence of the administered NPs) were determined in three rats' samples by group, chosen randomly. About $1 \mathrm{~g}$ samples of blood, brain and lungs were dried at $80^{\circ} \mathrm{C}$ to constant weight, and were digested in $5 \mathrm{ml}$ $65 \% \mathrm{HNO}_{3}$ at $90{ }^{\circ} \mathrm{C}$ for $90 \mathrm{~min}$. The digested matter was diluted 100 -fold, and metal levels were determined by inductively coupled plasma mass spectrometry at the Laboratory of the MOL Hungarian Oil and Gas Company.

\section{Electrophysiological Recording}

Preparation and electrophysiological recording was performed under urethane anesthesia (1000 mg/kg b.w. intraperitoneally; Koblin 2002). The rats' left hemisphere was surgically exposed by removing the parietal bone and a thin layer of petroleum jelly was applied on the dura to prevent drying (for details of preparation, see Oszlánczi et al. 2011).

For recording, the head of the rat was fixed in the stereotaxic frame of the electrophysiological setup. A thermostated $\left(+36.5^{\circ} \mathrm{C}\right)$ base plate was used to support the rat's underside and to stabilize body temperature during the recording procedure. Ball-tipped silver recording electrodes were placed on the dura over the primary somatosensory (SS) projection area of the whiskery pad, and over the primary visual (VIS) and auditory (AUD) focuses. The locations were determined on the basis of a somatotopic map (Zilles 1985), and the fine positioning of the electrodes was done by searching for the punctum maximum of the evoked response. A stainless steel clamp was attached to the cut skin edge as indifferent electrode.

Spontaneous electrical activity (electrocorticogram, ECoG) was recorded for $6 \mathrm{~min}$. From that, the relative spectral power of the frequency bands (delta, theta, alpha, beta1, beta2, gamma; standard human EEG bands as described by Kandel and Schwartz (1985) was determined. "ECoG index" was calculated from the relative band power data with the formula $([$ delta] $+[$ theta] $) /([$ beta1] $+[$ beta2] $)$. This proved to be a handy, albeit simplifying, descriptor of the ECoG spectrum in earlier works (Dési and Nagymajtényi 1999).

Then, sensory EPs were elicited and recorded. For SS EPs, square electric pulses were given through a pair of needles inserted into the whiskery skin $(3-4 \mathrm{~V} ; 0.05 \mathrm{~ms})$. VIS 
stimulation was performed by flashes delivered by a high-luminescence white LED directly into the contralateral eye of the rat. For AUD stimulation, clicks (ca. $40 \mathrm{~dB}$ ) were applied into the contralateral ear of the rat from a mini earphone through the hollow ear bar of the stereotaxic frame. From each modality, one series of 50 stimuli was applied at $1 \mathrm{~Hz}$ frequency, and onset latency of the recorded EPs was measured after averaging. For the SS EPs, frequency dependence of the latency was determined by delivering one series of stimuli to the whisker pad also with 2 and $10 \mathrm{~Hz}$ frequency, beyond the standard $1 \mathrm{~Hz}$. Previous studies (Papp et al. 2001) demonstrated that, by varying the frequency of stimulation, the dynamic interaction of successive excitation processes in the sensory system can be assessed, which in turn reflects the actual state of the CNS. The complete recording and evaluation was performed by the software NEUROSYS 1.11 (Experimetria Ltd., Hungary).

\section{Compliance with Ethical Standards}

During the whole study, the principles of the Ethical Committee for the Protection of Animals in Research of the University were strictly followed. The methods used in the experiments were licensed by the authority competent in animal welfare issues under No. XXI./151/2013.

\section{Data Analysis}

Normality test of data was done by the Kolmogorov-Smirnov test, then significance was tested with one-way ANOVA with post-hoc LSD test (IBM SPSS Statistics 22.0). Linear regression calculations between tissue metal levels and general- and neurotoxicological parameters were done by the "linear fit" function of MS Excel. The level of significance was set to $\mathrm{p}<0.05$.

\section{Results}

\section{Characteristics of the nanoparticles}

The TEM images (Figure 1) show morphology and size of NPs. The $\mathrm{MnO}_{2}$ NPs are very small, the spherical $\mathrm{Fe}_{3} \mathrm{O}_{4}$ crystals are clearly distinguishable and the $\mathrm{Cr}(\mathrm{OH})_{3}$ NPs are in the cloud of the amorphous part of this solid. Size distribution of NPs is shown in Figure 2A. The smallest $\mathrm{MnO}_{2} \mathrm{NPs}$ are of uniform size, while the primary particles of mainly amorphous $\mathrm{Cr}(\mathrm{OH})_{3}$ show very broad size distribution.

The dilute sols were in stable colloidal state, no sedimentation of NPs was observed. The measured average sizes and size distributions are characteristic of hydrodynamic units moving freely in the given aqueous media. Volume weighted size distribution of NPs at $\mathrm{pH} \sim 6.5$ and low salt content are shown in Figure 2B. The shape of distribution curves is similar to that in Figure 2A; however, the size ranges from DLS are ca. one order of magnitude larger than those observed by TEM. This is because TEM images show the size of primary cores of NPs, while DLS detects translational diffusion of particles which are coated with hydrate shell and adsorbed small or macro ions forming a steric and/or electric 
stabilizing layer around the cores. These hydrodynamic units may be aggregates of some primary cores.

The charge state of NPs in aqueous medium at $\mathrm{pH} \sim 6.5$ was characterized by the sign and magnitude of measured zeta potential. For the $\mathrm{Cr}(\mathrm{OH})_{3}$ NPs (uncoated, suspended in UP water) zeta potential was $+29.6 \mathrm{mV}$ (these NPs carry positive charges due to the protonation of surface hydroxyls at $\mathrm{pH}$ 6.5). The PAA coated NPs had negative zeta potential $\left(\mathrm{Fe}_{3} \mathrm{O}_{4}\right.$ :-44.4 $\mathrm{mV}, \mathrm{MnO}_{2}$ : $-24.2 \mathrm{mV}$; negative charge from dissociated - $\mathrm{COOH}$ groups in the coating shell at $\mathrm{pH} \sim 6.5$. All measured zeta potentials were sufficiently far from zero to provide for a stable colloidal suspension.

[Figure 1 and 2 near here]

\section{Body Weight Gain and Metal Levels in Tissue Samples}

Body weight gain of the animals treated with the metal NPs was significantly attenuated compared to the untreated control (Cont) from the first treatment week on (Figure 3). Decreased body weight gain was also seen in the vehicle control group ( $V C$ was significant vs. Cont), reflecting the effect of the treatment procedure (mainly the repeated diethyl ether anesthesia). Treatment with low $(M n L D)$ and high doses $(M n H D)$ of $\mathrm{MnO}_{2} \mathrm{NPs}$ significantly decreased body weight gain compared to $V C$ during the treatment period, especially in case of $M n H D$, where weight loss was seen at the end of the first week of the treatment period. In case of the combination treatments, $M F$ was not significantly different from $V C$, but combinations containing Cr NPs $(M C$ and $M F C$ ) showed significantly lower body weight gain. Diminished weight gain was more expressed after treatment with the double combination $M C$ than after the triple combination $M F C$.

[Figure 3 near here]

As shown by the data in Table 2, intratracheal instillation of metal NPs caused significant increase in the metal content of the tissue samples. In the lungs (at the site of NP entry) significant metal deposition was seen in case of $\mathrm{MnO}_{2}, \mathrm{Fe}_{3} \mathrm{O}_{4}$ and $\mathrm{Cr}(\mathrm{OH})_{3} \mathrm{NPs}$ as well, while in the blood and brain no elevation of Fe levels was seen compared to VC or Cont. On the contrary, significant increase of blood Mn levels was seen in all treatment groups (MnLD, MnHD and MF vs. Cont and VC; MC and MFC vs. Cont). In case of treatment with combinations containing $\mathrm{Cr}(\mathrm{OH})_{3} \mathrm{NPs}$, significant increase was seen in blood Cr levels $(M C$ and $M F C$ vs. Cont and VC), however, only a slight elevation occurred in the Cr content of the brain samples. Mn levels measured in the brain were increased in each treatment group exposed to $\mathrm{MnO}_{2}$ NPs ( $M n L D, M n H D, M F, M C$ and $M F C$ vs. Cont and $V C$ ).

[Table 2 near here]

By plotting the calculated body weight gain, and Mn levels measured in brain and blood samples, against the total applied Mn amount (calculated summed external dose in Table 3) for individual rats chosen for metal level measurement (3 per group, see Methods) one can see that the effect of the same Mn dose on the body weight gain was influenced by the other metal(s) applied (Figure 4A). In treatment groups exposed to $\mathrm{Fe}_{3} \mathrm{O}_{4} \mathrm{NPs}(M F$ and 
$M F C$ ) the body weight gain was generally less reduced than in Mn-only and $M C$ groups (the phenomenon can also be seen on the weight gain data presented in Figure 3). Although attenuated body weight gain caused by the combination treatments led to significantly lower summed external Mn doses in $M C, M F C$ and $M F$ groups (Table 3) than in $M n L D$, the internal Mn levels measured in brain samples of rats in groups $M C$ and $M F C$ were higher than in $M n L D$, while those measured in blood samples were lower than in $M n L D$ (Figure 4B, 4C; Table 2).

The correlation of metal level in blood and lungs to body weight gain was also significant (data not shown).

[Table 3 near here]

[Figure 4 near here]

\section{Cortical Electrical Activity}

In the spectral distribution of the ECoG, the proportion of the fast bands (beta1, beta2 and gamma) increased, while that of the slow bands (theta and delta) decreased upon metal NP treatment (Figure 5). In the SS ECoG, significant decrease of the delta band and increase of the gamma band was caused by Mn-only treatment (vs. Cont and $V C$ ). In the combinations $M C$ and $M F C$, these changes were also significant, though less pronounced. The proportion of bands changed minimally in group $M F$ (vs. Cont and $V C$ ). The observed alterations on the VIS ECoG (Figure 5) were similar to those of the SS ECoG, except that MnHD increased the proportion of fast bands more significantly, and the combination $M F$ also caused significant increase of the gamma band. The effect of $M n H D$ was similarly significant on the AUD ECoG, but only $M C$ treatment led to significant increase of the gamma band (vs. Cont and $V C)$.

Figure 6 shows significant correlation of the SS, VIS and AUD ECoG index (see Methods) to brain Mn levels in case of low (MnLD) and high dose (MnHD) $\mathrm{MnO}_{2} \mathrm{NP}$ treatment.

[Figure 5 near here]

[Figure 6 near here]

The SS EPs (Figure 7A) showed significantly increased latency on the action of $\mathrm{MnO}_{2}$ NPs and of $M C$ combination (and slightly of $M F C$, but it was significant exclusively at $2 \mathrm{~Hz}$ ). The latency increase was seen at all stimulation frequencies, and the frequency dependent extra lengthening (an indication of the actual state of the sensory pathway) was also altered by Mn-only and $M C$ treatments. The magnitude of latency increase was the highest in case of $M C$, while in group $M F$, no change was observed compared to $V C$. Changes in the VIS and AUD latencies were similar to SS EPs, i.e. significant increase was seen in case of $M n L D$ and $M n H D$ treatments, and partly in $M C$, vs. $V C$, but not in $M F$ (Figure 7B).

[Figure 7 near here] 
[Figure 8 near here]

When SS cortical EP latencies were plotted against brain Mn levels, significant correlation of latency data from low and high dose $\mathrm{MnO}_{2} \mathrm{NP}$ treatment to brain Mn levels was found at all stimulation frequencies (Figure 8 shows correlation of data at $10 \mathrm{~Hz}$ stimulation frequency; this represents maximal strain to the sensory pathway within the applied protocol at which any functional damage due to the treatment may be more conspicuous). Figure 8 also shows that SS EP latency data of rats receiving the $M C$ and $M F C$ combinations were increased compared to $M n L D$, while those in the $M F$ group were decreased. This phenomenon was in agreement with the data shown in Figure 7, namely that $\mathrm{Cr}(\mathrm{OH})_{3}$ plus $\mathrm{MnO}_{2}$ NPs together $(M C)$ had effects similar to Mn-only treatment; however, when $\mathrm{Fe}_{3} \mathrm{O}_{4}$ NPs were added to $\mathrm{MnO}_{2} \mathrm{NPs}(M F$ and $M F C$ ), there was only a slight or no change of latency vs. $V C$. In case of VIS and AUD EPs, the relationship of latency and inner Mn doses in the various treated groups was similar (data not shown).

\section{Discussion}

Our results indicated interactions between the applied metals in the general and nervous system effects which were not paralleled by the corresponding internal doses. The most conspicuous phenomenon concerning body weight gain as general toxicity parameter was the apparent protective role of $\mathrm{Fe}_{3} \mathrm{O}_{4} \mathrm{NP}$ co-treatment, seen in the weekly (Figure 3) and overall (Table 3) weight gain data, up to significantly less reduction of body weight gain in group $M F$ vs. $M n H D$. Presence of $\mathrm{Cr}(\mathrm{OH})_{3}$ NPs had no such effect, and diminished weight gain was more expressed after treatment with the double combination $(M C)$ than after the triple combination $(M F C)$. The correlation plots of the calculated body weight gain, and of the $\mathrm{Mn}$ levels in brain and blood samples, against the total applied Mn amount also reflected the diminished effect of Mn on body weight in presence of Fe (Figure 4A) without altering internal Mn doses (Figure 4B, 4C).

Of the two kinds of cortical activity recorded, EPs reflect alterations in synaptic transmission and axonal conduction more directly. Figure 7 shows that the latency of EPs was longer, and the extra latency lengthening of SS EP on higher frequency stimulation (2 or 10 $\mathrm{Hz}$ vs. $1 \mathrm{~Hz}$; Figure 7A) was increased, in the Mn-only and $M C$ combination groups compared to $V C$, but the difference of $M F$ vs. $V C$ was minimal. The increase in frequencydependent latency lengthening (a possible indicator of neuro-functional damage: Papp et al. 2001) could reflect impaired synaptic transmission and/or the consequences of oxidative stress and energetic shortage.

The efficacy of transmission is likely to be deteriorated as $\mathrm{Mn}^{2+}$ ions partly block presynaptic $\mathrm{Ca}$ channels, but also penetrate them, and cause intracellular Ca mobilization (Kita et al. 1981) which will decrease synchronous, but promote spontaneous, release of transmitters. In the case of $\mathrm{Cr}^{2+}$, a similar effect in the adrenal medulla was described (Liu and Lin 1997). The ion channel effects of the metals could affect both synaptic transmission and axonal conduction.

The main excitatory transmitter in the CNS is glutamate. After being released into the synaptic cleft and having activated the receptors, glutamate is taken up and converted to 
glutamine by the astrocytes. $\mathrm{Mn}^{2+}$ decreases both its uptake (Erikson and Aschner 2003) and transformation to glutamine (Normandin and Hazell 2001). Accumulation of excess glutamate at all transmission sites of the ascending sensory pathways may have resulted over the 4 weeks of exposure in receptor desensitization, possibly contributing to increased EP latency (Centonze et al. 2001). Excess glutamatergic activity could have also contributed to the observed increase of cortical activation (shift of the ECoG to higher frequencies), via the glutamatergic collaterals from the specific afferents to the ascending reticular formation.

The properties of the three metals (see Introduction) suggested the role of oxidative stress and/or mitochondrial damage in the mechanism of the observed effects. Mn is a welldocumented mitochondrial toxin, acting on complex II (Malecki 2001) and complex III (Zhang et al. 2003). Cr in the mitochondria oxidizes NADH and inhibits alpha-ketoglutarate dehydrogenase (Cohen et al. 1993). In mitochondrial Mn-SOD, surplus Fe tends to replace $\mathrm{Mn}$, decreasing enzyme activity (Bacon et al. 1993). Fenton reaction, a redox cycle characteristic for all three metals studied (Valko et al. 2005) can generate hydroxyl radicals within the mitochondria. The resulting oxidative stress could be responsible both for reduced body weight gain (due to the metabolic disturbance caused by free radicals: Merry 2002) and the neuro-functional effects. Generation of ROS in the brain has been reported with Mn (Zhang et al. 2009), Fe (Sayre et al. 1999) and Cr (Soudani et al. 2012). Peroxidation of membrane lipids leads to changes of fluidity and other properties which, in turn, disturb all membrane- and receptor-bound phenomena, such as synaptic transmission.

As seen in Figure 5 to Figure 8, the change of electrophysiological parameters was proportional to the relevant internal Mn load in the Mn-only groups, similar to the body weight effect; but was diminished in group $M F$, and partly in $M F C$, at comparable internal Mn levels. The diminishing action of Fe on the damage caused by Mn was hence not due to reduced presence of $\mathrm{Mn}$ in blood and brain, despite the common route of transport by transferrin into cells and through the BBB (Mn: Takeda 2003; Fe: Thompson et al. 2001; Cr: Vincent 2001). The method used to determine metal levels in biological samples in the present work did not distinguish between physicochemical forms (NPs or dissolved ions) but dissolution of the metal oxide NPs, at least partly, was likely (in the highly acidic lysosomes of phagocytes: Lundborg et al. 1985).

The interactions seen at the level of toxic effects and of internal dose were thus dissimilar; first of all, presence of Fe diminished the action of Mn on body weight and electrophysiological indicators without an effect on the internal Mn doses and, moreover, without an increase of brain Fe content (see Table 2). Instead, Fe possibly induced protective reactions with a more general effect. In cultured astrocytes (Gaasch et al. 2007) high dissolved Fe load stimulated induction of ferritin and downregulation of the transferrin receptor. This not only reduced transferrin-dependent uptake of $\mathrm{Mn}$ and $\mathrm{Cr}$ also but the stimulated astrocytes induced increased antioxidant defense in the nearby neurons, too. Lin et al. (2014) treated rat kidney-derived cells (NRK-52E) with $\mathrm{Fe}_{3} \mathrm{O}_{4} \mathrm{NPs}$ similar to ours and observed induction of anti-apoptotic protective proteins (glutathione reductase, glutathione-Stransferase, chaperon proteins). It seems conceivable that protective cellular reactions induced by Fe provide protection against $\mathrm{Mn}$ and $\mathrm{Cr}$ which have similar mechanisms of action. Such an effect would probably depend on the doses of the metals. In the present study, equal doses 
of the different NPs were administered to compare general toxicological and nervous system electrophysiological effects of welding fume NP exposure under identical treatment conditions. To overcome this limitation, it is a task for the future to investigate the interaction of the three metals using doses that represent the composition of real welding fumes.

\section{Conclusion}

The results described and evaluated above underline that the biological effects of complex metal exposures cannot be understood from the effects of the individual metals only. Animal models like the one used in the present study provide essential information for better understanding of such complex exposures, and, indirectly, for higher level of occupational hygiene.

\section{Limitations of the study}

Pulmonary toxicity of the applied NPs was not studied in the present experiment. In a future work histopathological evaluation and bronchoalveolar lavage analysis should be carried out to improve the evaluation of toxic effects.

\section{Acknowledgements}

The authors wish to thank to Dr. Attila Szöke, Mr. József Koszta and Ms. Edit Pálinkás at the Laboratory of the MOL Hungarian Oil and Gas Company for the metal level determinations.

\section{Disclosure of Interest:}

The authors report no conflicts of interest. 


\section{References}

[ACGIH] American Conference of Governmental Industrial Hygienists. 1991-2012.

Documentation of the Threshold Limit Values and Biological Exposure Indices. [accessed 2017 May 03]. www.acgih.org.

Antonini JM, Lewis AB, Roberts JR, Whaley DA. 2003. Pulmonary effects of welding fumes: review of worker and experimental animal studies. Am J Ind Med. 43:350-360. DOI: 10.1002/ajim.10194.

Antonini JM, Roberts JR, Chapman RS, Soukup JM, Ghio AJ, Sriram K. 2010. Pulmonary toxicity and extrapulmonary tissue distribution of metals after repeated exposure to different welding fumes. Inhal Toxicol. 22:805-816. DOI: 10.3109/08958371003621641.

Avila DS, Gubert P, Fachinetto R, Wagner C, Aschner M, Rocha JB, Soares FA. 2008. Involvement of striatal lipid peroxidation and inhibition of calcium influx into brain slices in neurobehavioral alterations in a rat model of short-term oral exposure to manganese. Neurotoxicology. 29:1062-1068. DOI:10.1016/j.neuro.2008.08.004.

Bacon BR, O’Neill R, Britton RS. 1993. Hepatic mitochondrial energy production in rats with chronic iron overload. Gastroenterology. 105:1134-1140.

Bowler RM, Koller W, Schulz PE. 2006. Parkinsonism due to manganism in a welder: neurological and neuro- psychological sequelae. Neurotoxicology. 27:327-332. DOI: 10.1016/j.neuro.2005.10.011.

Calne DB, Chu NS, Huang CC, Lu CS, Olanow W. 1994. Manganism and idiopathic Parkinsonism: Similarities and differences. Neurology. 44:1583-1586.

Centonze D, Gubellini P, Bernardi G, Calabresi P. 2001. Impaired excitatory transmission in the striatum of rats chronically intoxicated with manganese. Exp Neurol. 172:469476. DOI: 10.1006/exnr.2001.7812.

Chang Y, Woo ST, Kim Y, Lee JJ, Song HJ, Lee HJ, Kim SH, Lee H, Kwon YJ, Ahn JH, et al. 2010. Pallidal index measured with three-dimensional T1-weighted gradient echo sequence is a good predictor of manganese exposure in welders. J Magn Reson Imaging. 31:1020-1026. DOI: 10.1002/jmri.22104.

Cohen MD, Kargacin B, Klein CB, Costa M. 1993. Mechanisms of chromium carcinogenicity and toxicity. Crit Rev Toxicol. 23:255-281.

Demchak R, Matijević E. 1969. Preparation and particle size analysis of chromium hydroxide hydrosols of narrow size distributions. J Colloid Interface Sci. 31:257-262. DOI:10.1016/0021-9797(69)90334-8

Derelanko MJ, Rinehart WE, Hilaski RJ, Thompson RB, Löser E. 1999. Thirteen-week subchronic rat inhalation toxicity study with a recovery phase of trivalent chromium compounds, chromic oxide, and basic chromium sulfate. Toxicol Sci. 52:278-288.

Dési I, Nagymajtényi L. 1999. Electrophysiological biomarkers of an organophosphorous pesticide, dichlorvos. Toxicol Lett. 107:55-64. DOI: 10.1016/S0378-4274(99)000314. 
Diaz-Mayans J, Laborda R, Nunez A. 1986. Hexavalent chromium effects on motor activity and some metabolic aspects of wistar albino rats. Comp Biochem Physiol C. 83:191195.

Elder A, Gelein R, Silva V, Feikert T, Opanashuk L, Carter J, Potter R, Maynard A, Ito Y, Finkelstein J, Oberdörster G. 2006. Translocation of ultrafine manganese oxide particles to the central nervous system. Environ Health Perspect. 114:1172-1178.

Erikson KM, Aschner M. 2003. Manganese neurotoxicity and glutamate-GABA interaction. Neurochem Int. 43:475-480.

Filho WJ, Fontinele RG, de Souza RR. 2014. Reference database of lung volumes and capacities in Wistar rats from 2 to 24 months. Curr Aging Sci. 7:220-228.

Frei B, Higdon JV. 2003. Antioxidant Activity of Tea Polyphenols In Vivo: Evidence from Animal Studies. J Nutr. 133:3275S-3284S.

Gaasch JA, Lockman PR, Geldenhuys WJ, Allen DD, Van der Schyf CJ. 2007. Brain iron toxicity: differential responses of astrocytes, neurons, and endothelial cells. Neurochem Res. 32:1196-1208. DOI: 10.1007/s11064-007-9290-4.

Guo Q, Zhao B, Li M, Shen S, Xin W. 1996. Studies on protective mechanisms of four components of green tea polyphenols against lipid peroxidation in synaptosomes. Biochim Biophys Acta. 1304:210-222. DOI:10.1016/S0005-2760(96)00122-1.

Hajdú A, Szekeres M, Tóth IY, Bauer RA, Mihály J, Zupkó I, Tombácz E. 2012. Enhanced stability of polyacrylate-coated magnetite nanoparticles in biorelevant media. Colloids Surf B Biointerfaces. 94:242-249. DOI:10.1016/j.colsurfb.2012.01.042

HaMai D, Bondy SC. 2004. Oxidative basis of manganese neurotoxicity. Ann N Y Acad Sci. 1012:129-141.

Horie M, Nishio K, Endoh S, Kato H, Fujita K, Miyauchi A, Nakamura A, Kinugasa S, Yamamoto K, Niki E, et al. 2013. Chromium(III) oxide nanoparticles induced remarkable oxidative stress and apoptosis on culture cells. Environ Toxicol. 28:61-75. DOI: 10.1002/tox.20695.

Horváth E, Máté Z, Takács S, Pusztai P, Sápi A, Kónya Z, Nagymajtényi L, Papp A. 2012. General and electrophysiological toxic effects of manganese in rats following subacute administration in dissolved and nanoparticle form. ScientificWorldJournal. Article ID 520632, 7 pages. [accessed 2016 Dec 8]. http://dx.doi.org/10.1100/2012/520632.

[ICRP] International Commission on Radiological Protection. 1994. Human respiratory tract model for radiological protection. A report of a task group of the ICRP. ICRP Publication 66. Ann ICRP. 24:1-482.

Jenkins NT. 2003. Chemistry of airborne particles from metallurgical processing [dissertation]. Cambridge (MA): Massachusetts Institute of Technology. [accessed 2016 Dec 1]. https://dspace.mit.edu/handle/1721.1/17033.

Kandel ER, Schwartz JH. 1985. Principles of Neural Science. Elsevier: New York. p. 643644.

Kita H, Narita K, Van der Kloot W. 1981. Tetanic stimulation increase the frequency of miniature end-plate potentials at the frog neuromuscular junction in $\mathrm{Mn}^{2+}-\mathrm{Co}^{2+}$, and $\mathrm{Ni}^{2+}$-saline solutions. Brain Res. 205:111-121.

Koblin DD. 2002. Urethane: help or hindrance? Anesth Analg. 94:241-242. 
Korczynski RE. 2000. Occupational health concerns in the welding industry. Appl Occup Environ Hyg. 15:936-945. DOI: 10.1080/104732200750051175.

Kreyling WG, Semmler-Behnke M, Möller W. 2006. Ultrafine particle-lung interactions: Does size matter? J Aerosol Med. 19:74-83. DOI: 10.1089/jam.2006.19.74.

Lieberman H. 1941. Chrome ulcerations of the nose and throat. N Eng J Med. 225:132-133. DOI: 10.1056/NEJM194107242250402.

Lin YR, Kuo CJ, Lin HYH, Wu CJ, Liang SS. 2014. A proteomics analysis to evaluate cytotoxicity in NRK-52E cells caused by unmodified nano- $\mathrm{Fe}_{3} \mathrm{O}_{4}$.

ScientificWorldJournal. Article ID 754721, 9 pages. [accessed 2016 Nov 28]. http://dx.doi.org/10.1155/2014/754721.

Liu PS, Lin MK. 1997. Biphasic effects of chromium compounds on catecholamine secretion from bovine adrenal medullary cells. Toxicology. 117:45-53.

Lundborg M, Eklund A, Lind DB, Camner P. 1985. Dissolution of metals by human and rabbit alveolar macrophages. Br J Ind Med. 42:642-645.

Malecki EA. 2001. Manganese toxicity is associated with mitochondrial dysfunction and DNA fragmentation in rat primary striatal neurons. Brain Res Bull. 55:225-228. DOI: 10.1016/S0361-9230(01)00456-7.

Máté Z, Szabó A, Paulik E, Jancsó Z, Hermesz E, Papp A. 2011. Electrophysiological and biochemical response in rats on intratracheal instillation of manganese. Centr Eur $\mathbf{J}$ Biol. 6:925-932. DOI:10.2478/s11535-011-0080-2.

Merry BJ. 2002. Molecular mechanisms linking calorie restriction and longevity. Int J Biochem Cell Biol. 34:1340-1354.

Milner CE, inventor; E. I. DuPont de Nemours and Company, assignee. 1993 Dec 7. Process for the preparation of colloidal manganese dioxide. United States patent US 5,268,408.

Normandin L, Hazell AS. 2001. Manganese neurotoxicity: an update of pathophysiologic mechanisms. Metab Brain Dis. 17:375-387. DOI: 10.1023/A:1021970120965.

Oberdörster G, Oberdörster E, Oberdörster J. 2005. Nanotoxicology: An emerging discipline evolving from studies of ultrafine particles. Environ Health Perspect. 113:823-839.

Oka Y, Mitsui M, Kitahashi T, Sakamoto A, Kusuoka O, Tsunoda T, Mori T, Tsutsumi M. 2006. A reliable method for intratracheal instillation of materials to the entire lung in rats. J Toxicol Pathol. 19:107-109. DOI: 10.1293/tox.19.107.

Ono K, Komai K, Yamada M. 2002. Myoclonic involuntary movement associated with chronic manganese poisoning. J Neurol Sci. 199:93-96. DOI:10.1016/S0022510X(02)00111-9.

Oszlánczi G, Vezér T, Sárközi L, Horváth E, Kónya Z, Papp A. 2010. Functional neurotoxicity of Mn-containing nanoparticles in rats. Ecotoxicol Environ Saf. 73:2004-2009. DOI:10.1016/j.ecoenv.2010.09.002.

Oszlánczi G, Papp A, Szabó A, Nagymajtényi L, Sápi A, Kónya Z, Paulik E, Vezér T. 2011. Nervous system effects in rats on subacute exposure by lead-containing nanoparticles via the airways. Inhal Toxicol. 23:173-181. DOI: 10.3109/08958378.2011.553248.

Papp A, Vezér T, Institóris L. 2001. An attempt to interpret the fatigue of the somatosensory cortical evoked potential during a stimulus train as a possible biomarker of neurotoxic exposure. Centr Eur J Occup Environ Med. 7:276-281. 
Park JD, Kim KY, Kim DW, Choi SJ, Choi BS, Chung YH, Han JH, Sung JH, Kwon IH, Mun JH, Yu IJ. 2007. Tissue distribution of manganese in iron-sufficient or irondeficient rats after stainless steel welding-fume exposure. Inhal Toxicol. 19:563-572. DOI:10.1080/08958370701276554

Repetto G, del Peso A, Salguero M, Garfia A, Sanz P, Repetto M. 1996. Comparative effects of three chromium compounds on mouse neuroblastoma cells cultured in vitro. Toxicol Lett. 88:41-42.

Roduit N. JMicroVision: Image analysis toolbox for measuring and quantifying components of high-definition images. Version 1.2.7. http://www.jmicrovision.com (Accessed 2 September 2016).

Saric M, Markicevic A, Hrustic O. 1977. Occupational exposure to manganese. Br J Ind Med. 34:114-118.

Sárközi K, Papp A, Horváth E, Máté Z, Hermesz E, Kozma G, Zomborszki ZP, Kálomista I, Galbács G, Szabó A. 2017. Protective effect of green tea against neuro-functional alterations in rats treated with $\mathrm{MnO}_{2}$ nanoparticles. J Sci Food Agric. 97:1717-1724. DOI:10.1002/jsfa.7919.

Sayre LM, Perry G, Smith MA. 1999. Redox metals and neurodegenerative disease. Curr Opin Chem Biol. 3:220-225. DOI: 10.1016/S1367-5931(99)80035-0.

Sinczuk-Walczak H, Jakubowski M, Matczak W. 2001. Neurological and neurophysiological examinations of workers occupationally exposed to manganese. Int J Occup Med Environ Health. 14:329-337.

Soudani N, Troudi A, Amara IB, Bouaziz H, Boudawara T, Zeghal N. 2012. Ameliorating effect of selenium on chromium (VI)-induced oxidative damage in the brain of adult rats. J Physiol Biochem. 68:397-409. DOI: 10.1007/s13105-012-0152-4.

Takeda A. 2003. Manganese action in brain function. Brain Res Rev. 41:79-87. DOI: 10.1016/S0165-0173(02)00234-5.

Theegarten D, Boukercha S, Philippou S, Anhann O. 2010. Submesothelial deposition of carbon nanoparticles after toner exposition: Case report. Diagn Pathol. 5:77. DOI:10.1186/1746-1596-5-77.

Thompson KJ, Shoham S, Connor JR. 2001. Iron and neurodegenerative disorders. Brain Res Bull. 55:155-164. DOI: 10.1016/S0361-9230(01)00510-X.

Valko M, Morris H, Cronin MT. 2005. Metals, toxicity and oxidative stress. Curr Med Chem. 12:1161-1208. DOI: 10.2174/0929867053764635.

Vezér T, Papp A, Hoyk Z, Varga C, Náray M, Nagymajtényi L. 2005. Behavioral and neurotoxicological effects of subchronic manganese exposure in rats. Environ Toxicol Pharmacol. 19:797-810. DOI:10.1016/j.etap.2004.12.046.

Vincent JB. 2001. The bioinorganic chemistry of chromium(III). Polyhedron Report No. 68. Polyhedron. 20:1-26. DOI: 10.1016/S0277-5387(00)00624-0.

Zhang J, Fitsanakis VA, Gu G, Jing D, Ao M, Amarnath V, Montine TJ. 2003. Manganese ethylene-bis-dithiocarbamate and selective dopaminergic neurodegeneration in rat: a link through mitochondrial dysfunction. J Neurochem. 84:336-346. DOI: 10.1046/j.1471-4159.2003.01525.x. 
Zhang P, Wong TA, Lokuta KM, Turner DE, Vujisic K, Liu B. 2009. Microglia enhance manganese chloride-induced dopaminergic neurodegeneration: Role of free radical generation. Exp Neurol. 217:219-230. DOI: 10.1016/j.expneurol.2009.02.013.

Zilles K. 1985. The cortex of the rat. A stereotaxic atlas. Springer: Berlin. 
Table 1. Treatment groups and daily doses.

\begin{tabular}{llc}
\hline Group code & Dose and treatment $(/ \mathbf{k g ~ b . w . )}$ & $\mathbf{n}$ \\
\hline Cont & untreated control & 6 \\
$V C$ & $1 \mathrm{ml} \mathrm{PAA}+1 \mathrm{ml}$ normal saline; vehicle control & 8 \\
$M n L D$ & $2 \mathrm{mg} \mathrm{MnO}_{2} ;$ low dose & 8 \\
$M n H D$ & $4 \mathrm{mg} \mathrm{MnO}_{2} ;$ high dose & 8 \\
$M F$ & $2 \mathrm{mg} \mathrm{MnO}_{2}+2 \mathrm{mg} \mathrm{Fe}_{3} \mathrm{O}_{4} ;$ double combination & 8 \\
$M C$ & $2 \mathrm{mg} \mathrm{MnO}_{2}+2 \mathrm{mg} \mathrm{Cr}(\mathrm{OH})_{3} ;$ double combination & 8 \\
$M F C$ & $2 \mathrm{mg} \mathrm{MnO}_{2}+2 \mathrm{mg} \mathrm{Fe}_{3} \mathrm{O}_{4}+2 \mathrm{mg} \mathrm{Cr}(\mathrm{OH})_{3} ;$ triple combination & 8 \\
\hline
\end{tabular}


Table 2. Metal levels in blood, brain and lung samples.

\begin{tabular}{|c|c|c|c|c|c|c|c|c|}
\hline & \multicolumn{8}{|c|}{ Tissue metal levels $(\mu \mathrm{g} / \mathrm{kg})$} \\
\hline & & Cont & $V C$ & $M n L D$ & $M n H D$ & $M F$ & $M C$ & $M F C$ \\
\hline \multirow{3}{*}{$\frac{\vec{\partial}}{\frac{0}{0}}$} & $\mathrm{Fe}$ & $\begin{array}{l}2298240.75 \\
\pm 20150.90\end{array}$ & $\begin{array}{r}2249378.68 \\
\pm 396766.73\end{array}$ & - & - & $\begin{array}{l}2369477.75 \\
\pm 58384.64\end{array}$ & - & $\begin{array}{c}2324487.14 \\
\pm 52554.01\end{array}$ \\
\hline & Mn & $\begin{array}{l}278.84 \\
\pm 79.56\end{array}$ & $\begin{array}{l}309.41 \\
\pm 97.19\end{array}$ & $\begin{array}{c}533.44 \\
\pm 99.94^{* \#}\end{array}$ & $\begin{array}{c}715.21 \\
\pm 176.01^{* \#}\end{array}$ & $\begin{array}{c}530.46 \\
\pm 79.46 * \#\end{array}$ & $\begin{array}{c}432.76 \\
\pm 37.21 *\end{array}$ & $\begin{array}{c}436.16 \\
\pm 22.51 *\end{array}$ \\
\hline & $\mathrm{Cr}$ & $\begin{array}{l}142.90 \\
\pm 16.06\end{array}$ & $\begin{array}{l}138.71 \\
\pm 10.67\end{array}$ & - & - & - & $\begin{array}{c}639.85 \\
\pm 107.24 * * \#\end{array}$ & $\begin{array}{c}520.85 \\
\pm 165.54 * \#\end{array}$ \\
\hline \multirow{3}{*}{ טี } & $\mathrm{Fe}$ & $\begin{array}{c}85243.51 \\
\pm 3719.38\end{array}$ & $\begin{array}{l}80222.65 \\
\pm 9683.69\end{array}$ & - & - & $\begin{array}{c}82831.18 \\
\pm 10200.72\end{array}$ & - & $\begin{array}{c}80890.50 \\
\pm 5209.78\end{array}$ \\
\hline & Mn & $\begin{array}{l}2010.17 \\
\pm 354.19\end{array}$ & $\begin{array}{l}1897.94 \\
\pm 289.96\end{array}$ & $\begin{array}{c}5548.28 \\
\pm 518.42 * * * \# \#\end{array}$ & $\begin{array}{c}8159.31 \\
\pm 673.97 * * * \# \#{ }^{\circ}\end{array}$ & $\begin{array}{c}5495.31 \\
\pm 512.58 * * * \# \#\end{array}$ & 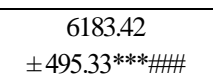 & $\begin{array}{c}6351.18 \\
\pm 671.70^{* * * \# \#}\end{array}$ \\
\hline & $\mathrm{Cr}$ & $\begin{array}{r}122.70 \\
\pm 15.01\end{array}$ & $\begin{array}{c}146.84 \\
\pm 42.40\end{array}$ & - & - & - & $\begin{array}{c}277.04 \\
\pm 180.34\end{array}$ & $\begin{array}{c}200.26 \\
\pm 94.02\end{array}$ \\
\hline \multirow{3}{*}{ 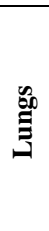 } & $\mathbf{F e}$ & $\begin{array}{l}386146.30 \\
\pm 27269.51\end{array}$ & $\begin{array}{l}347220.77 \\
\pm 61025.06\end{array}$ & - & - & $\begin{array}{c}9933993.95 \\
\pm 3392692.31^{* * \# \#}\end{array}$ & - & $\begin{array}{c}7693587.62 \\
\pm 934597.04 * * * \# \#\end{array}$ \\
\hline & Mn & $\begin{array}{l}1256.71 \\
\pm 417.31\end{array}$ & $\begin{array}{c}1550.57 \\
\pm 279.68\end{array}$ & $\begin{array}{c}11739.03 \\
\pm 458.71^{* * * \# \#}\end{array}$ & $\begin{array}{l}11747.39 \\
\pm 7547.83\end{array}$ & $\begin{array}{c}6947.20 \\
\pm 2134.28^{*} \#\end{array}$ & $\begin{array}{c}8696.07 \\
\pm 1321.46^{* * * \# \#}\end{array}$ & $\begin{array}{c}10162.93 \\
\pm 2215.36 * \text { *\# }\end{array}$ \\
\hline & $\mathrm{Cr}$ & $\begin{array}{l}215.45 \\
\pm 34.95\end{array}$ & $\begin{array}{r}179.54 \\
\pm 33.43\end{array}$ & - & - & - & $\begin{array}{c}7862358.03 \\
\pm 960490.48 * * * \# \#\end{array}$ & $\begin{array}{c}5162283.66 \\
\pm 489893.10^{* * * \# \#}\end{array}$ \\
\hline
\end{tabular}

Mean \pm SD, $n=3$

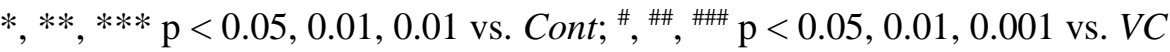


Table 3. Body weight gain over the 4 weeks of metal NP exposure, and summed metal dose calculated for the same period.

\begin{tabular}{|c|c|c|c|c|}
\hline \multirow[b]{2}{*}{ Groups } & \multirow[t]{2}{*}{ Body weight gain (g) } & \multicolumn{3}{|c|}{ Calculated summed external metal load (mg/rat) } \\
\hline & & Mn & $\mathbf{F e}$ & $\mathrm{Cr}$ \\
\hline Cont & $150.17 \pm 12.83$ & - & - & - \\
\hline$V C$ & $111.1 \pm 19.02 * * *$ & - & - & - \\
\hline$M n L D$ & 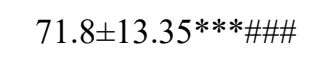 & $8.15 \pm 0.45$ & - & - \\
\hline$M n H D$ & $37.67 \pm 24.18 * * * \# \# \#^{\circ \circ}$ & $14.96 \pm 1.24^{\circ 00}$ & - & - \\
\hline$M F$ & $115.56 \pm 19.79 * *$ & $7.22 \pm 0.45^{\circ \circ \circ}$ & $2.76 \pm 0.17$ & - \\
\hline$M C$ & $89.3 \pm 20.35^{* * * \#}$ & $7.15 \pm 0.35^{\circ 0 \circ}$ & - & $5.71 \pm 0.28$ \\
\hline$M F C$ & $102.13 \pm 15.06 * * *$ & $6.48 \pm 1.7^{\circ 0}$ & $2.48 \pm 0.65$ & $5.18 \pm 1.35$ \\
\hline
\end{tabular}

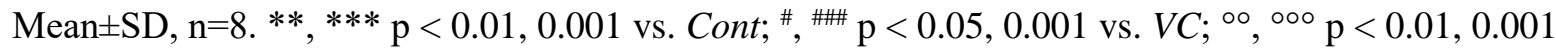
vs. $M n L D$

The summed external metal load was calculated by adding individual daily doses which were calculated on the basis of daily body weights, group doses given in Table 1, and metal content of the NPs according to their formula. 

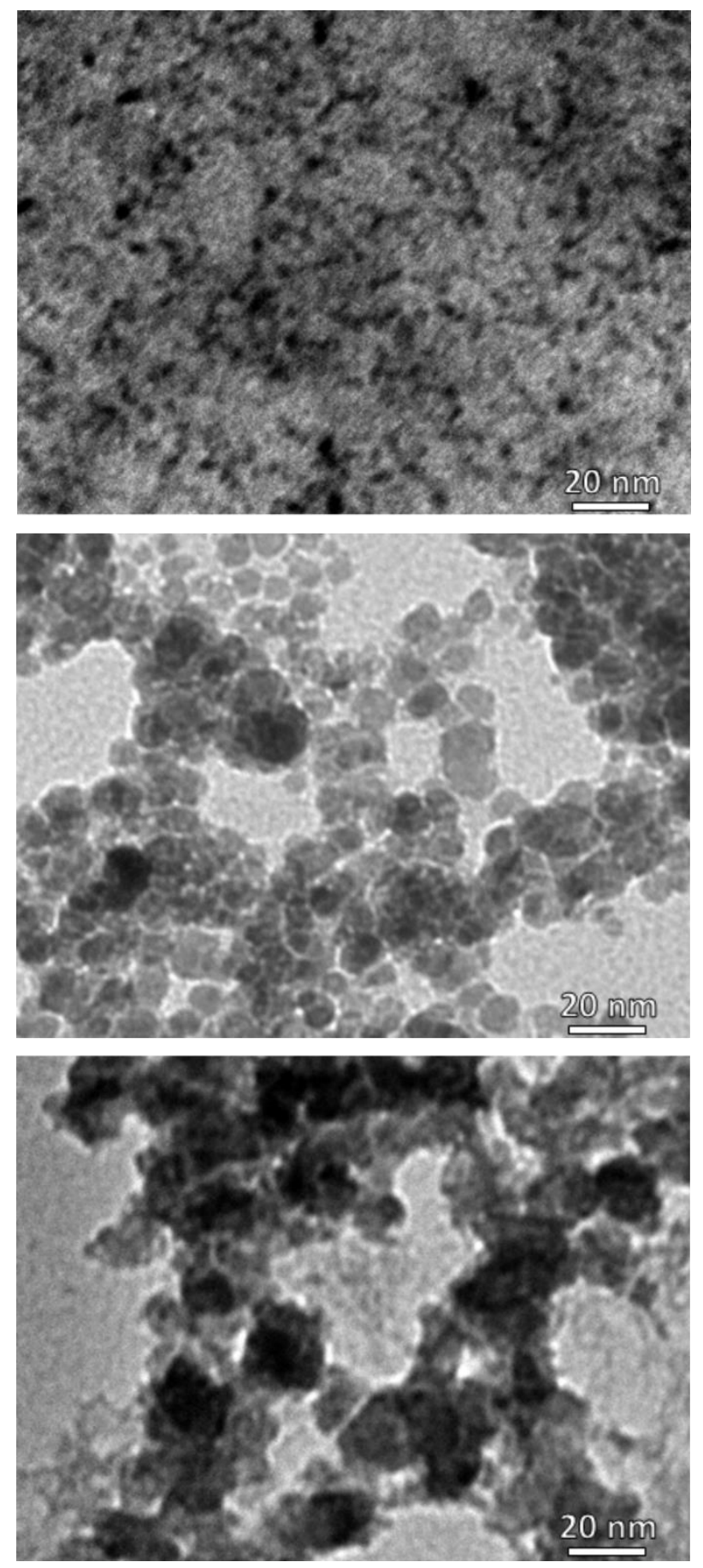

\section{Figure 1.}

TEM images of $\mathrm{MnO}_{2}$ (top), $\mathrm{Fe}_{3} \mathrm{O}_{4}$ (middle) and $\mathrm{Cr}(\mathrm{OH})_{3}$ (bottom) NPs. 

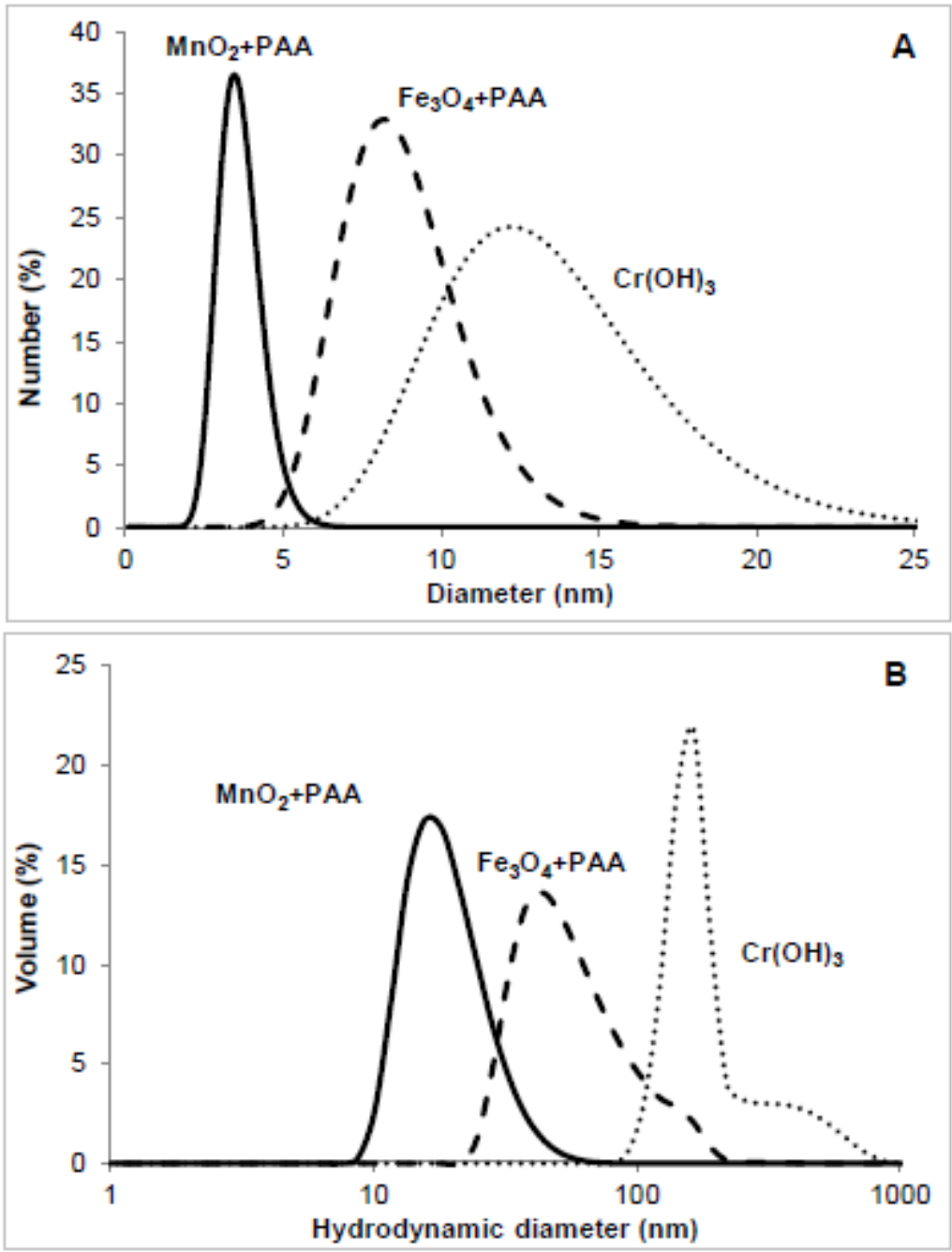

\section{Figure 2.}

A: Evaluation of TEM images to compare size and size distribution of the different NPs dried on the TEM grid from their dilute sols. Average diameters of primary $\mathrm{MnO}_{2}, \mathrm{Fe}_{3} \mathrm{O}_{4}$ and $\mathrm{Cr}(\mathrm{OH})_{3}$ NPs are 3.6, 8.8 and $13.5 \mathrm{~nm}$, respectively. Size distributions were calculated from evaluating approximately 100 particles. B: Volume weighted size distribution of NPs in dilute aqueous sols at $\mathrm{pH} \sim 6.5$. 


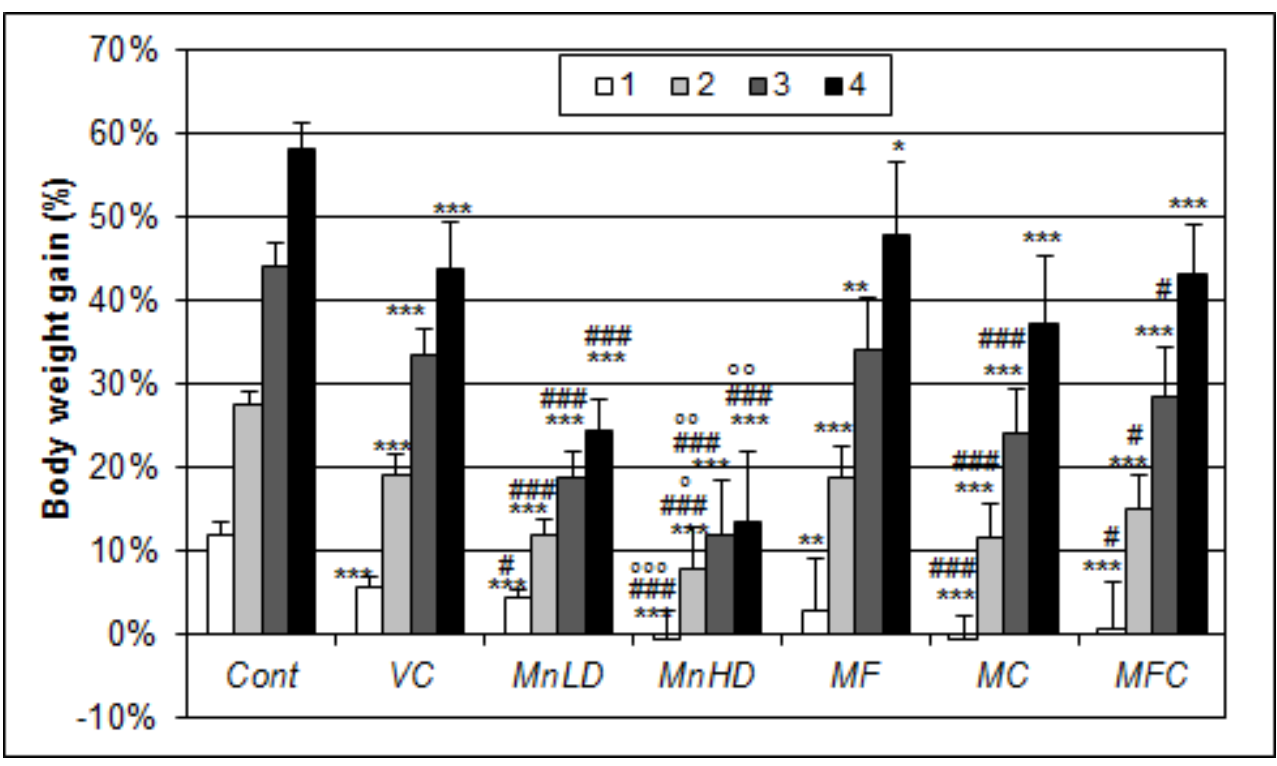

Figure 3.

Body weight gain of the rats during the 4 weeks of metal NP exposure. Mean+SD, $n=8$. Weekly body weight gain - as the difference of body weight on Friday of the given week and Friday of the pre-treatment week - was calculated in percentage separately for each rat, then averaged group by group. Insert: weeks of exposure.

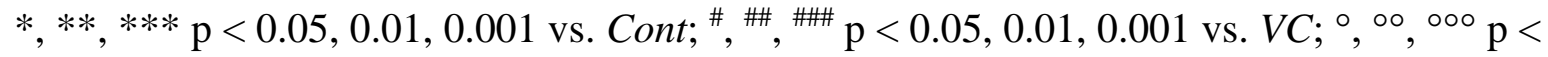
$0.05,0.01,0.001$ vs. $M n L D$. 

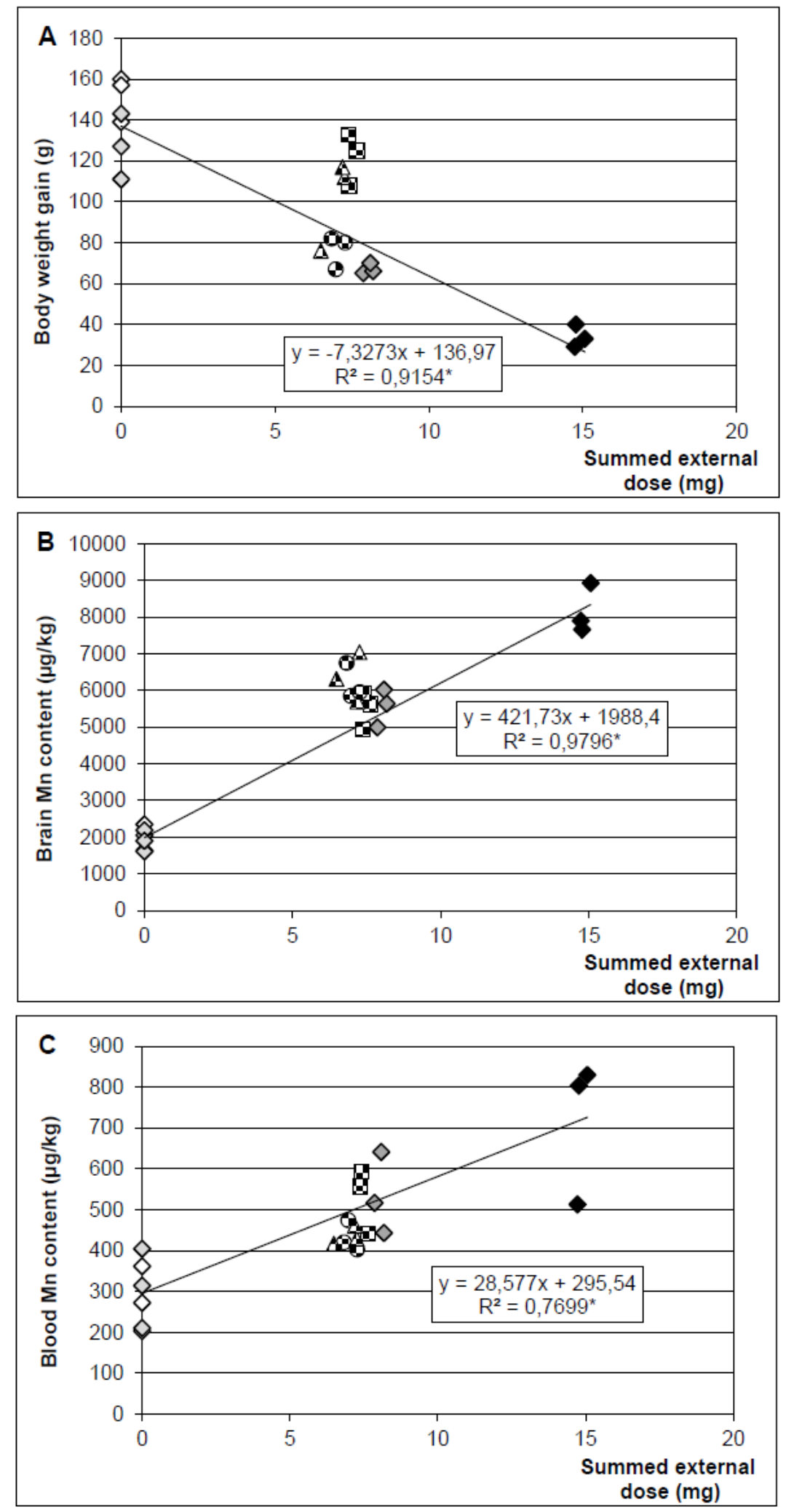

\section{Figure 4.}

Correlation of body weight gain (A), and of brain (B) and blood (C) Mn levels (ordinate) to summed external Mn dose (abscissa). Each point represents a data pair from an individual rat chosen for metal level measurement (see Methods). 
Light symbols, Cont; light grey symbols, $V C$; dark grey symbols, $M n L D$; black symbols, $M n H D$. Patterned symbols indicate combinations of NPs: squares, $M F$; circles, $M C$; triangles, $M F C$. Inserts: equation and $\mathrm{R}^{2}$ of the line fitted on Cont, MnLD, MnHD points; *: $\mathrm{p}<0.05$ (Ftest for the linear fit).
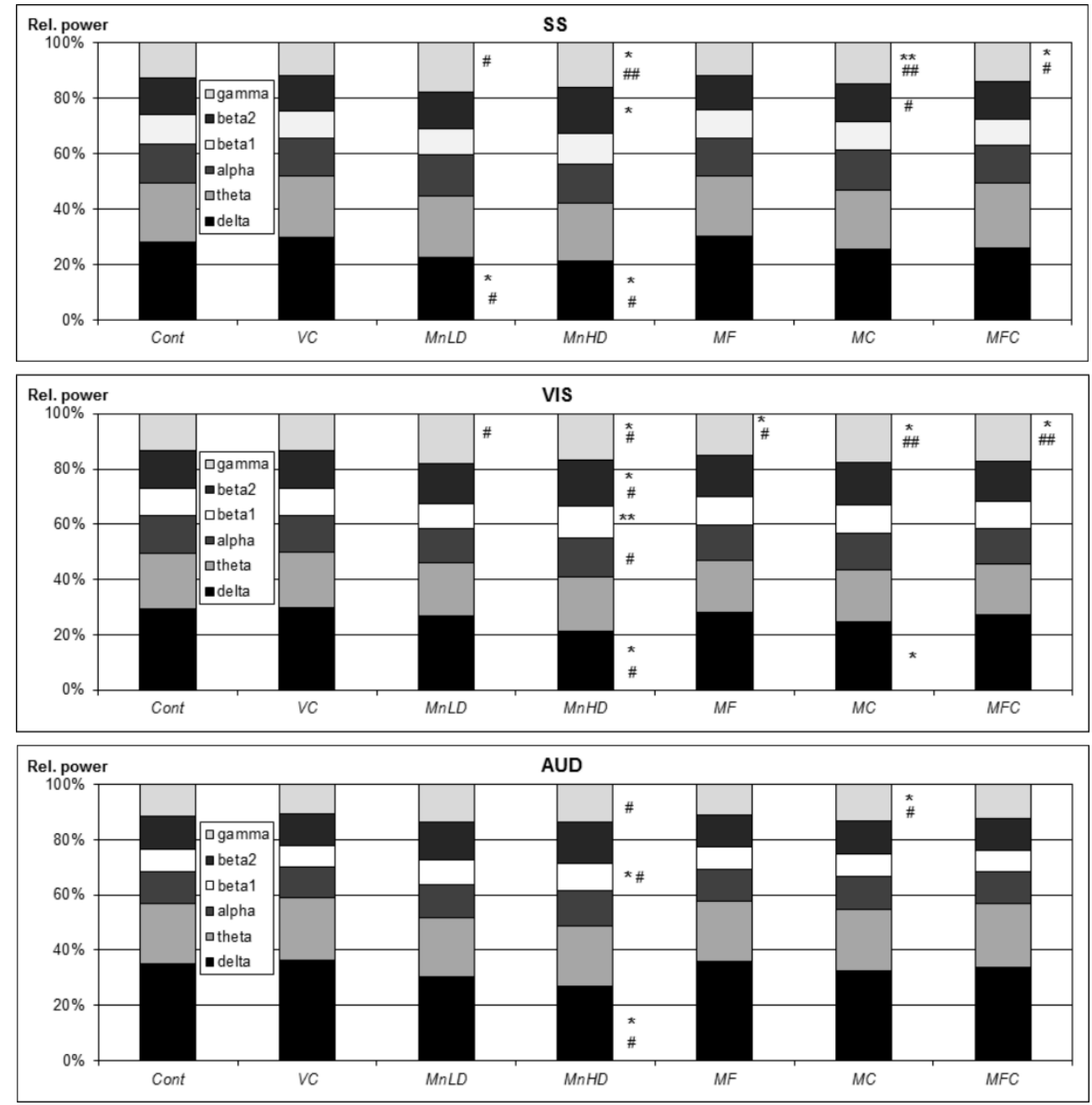

Figure 5.

Power spectrum of the ECoG from the three cortical areas after 4 weeks of exposure to metal NPs. Abscissa, groups; ordinate, relative power of ECoG bands (see insert). $*, * * \mathrm{p}<0.05,0.01$ vs. Cont; ${ }^{\#}{ }^{\# \#} \mathrm{p}<0.05,0.01$ vs. $V C$. 


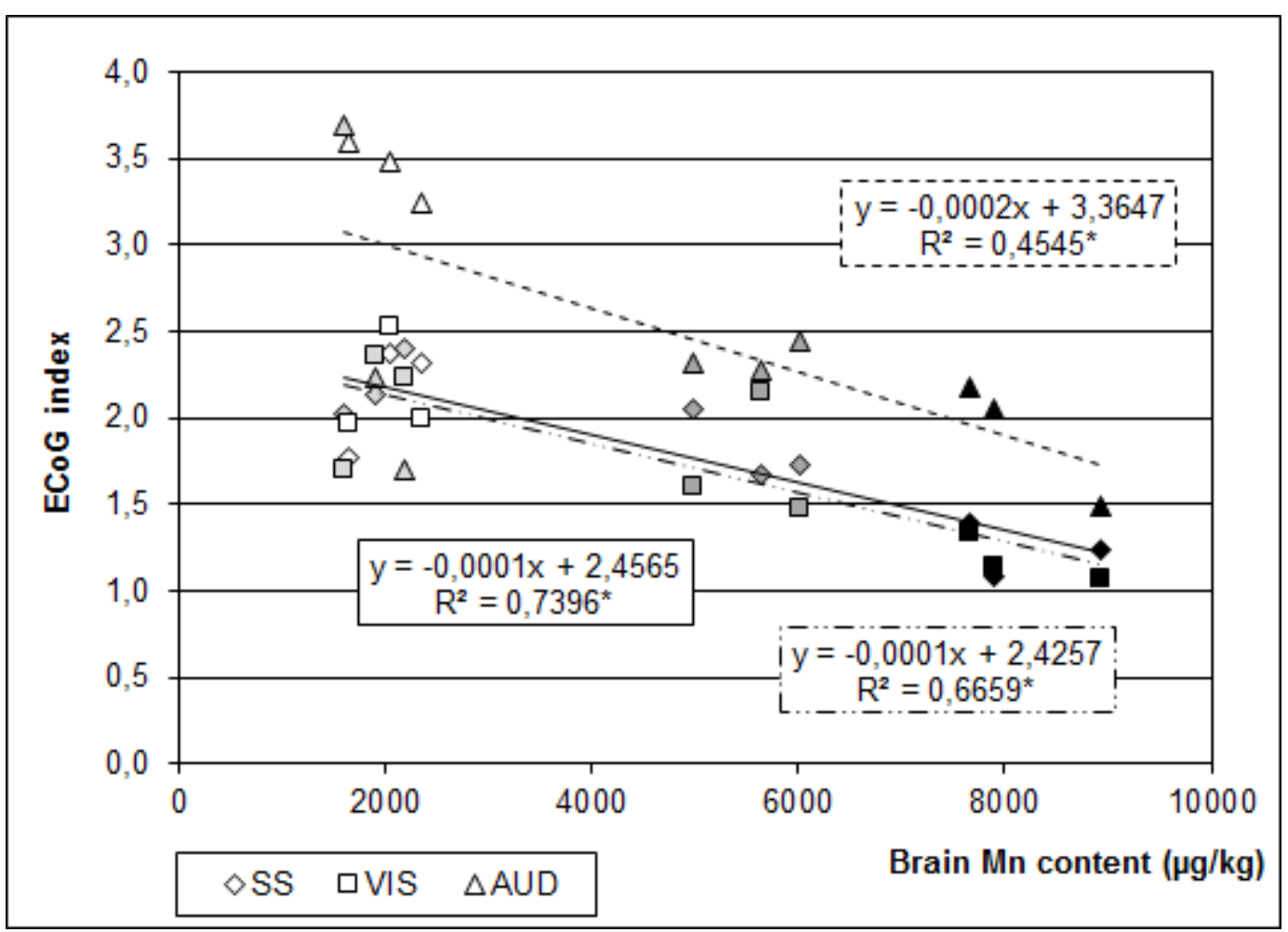

\section{Figure 6.}

Correlation of SS, VIS and AUD ECoG index (ordinate) to brain Mn levels (abscissa). Each point represents a data pair (see insert at the bottom for corresponding sensory modality) from an individual rat chosen for metal level measurement (see Methods).

Light symbols, Cont; light grey symbols, $V C$; dark grey symbols, $M n L D$; black symbols, $M n H D$. Inserts with outlines corresponding to the fitted lines: equation and $\mathrm{R}^{2} ; *$ : $\mathrm{p}<0.05$ (Ftest for the linear fit). 

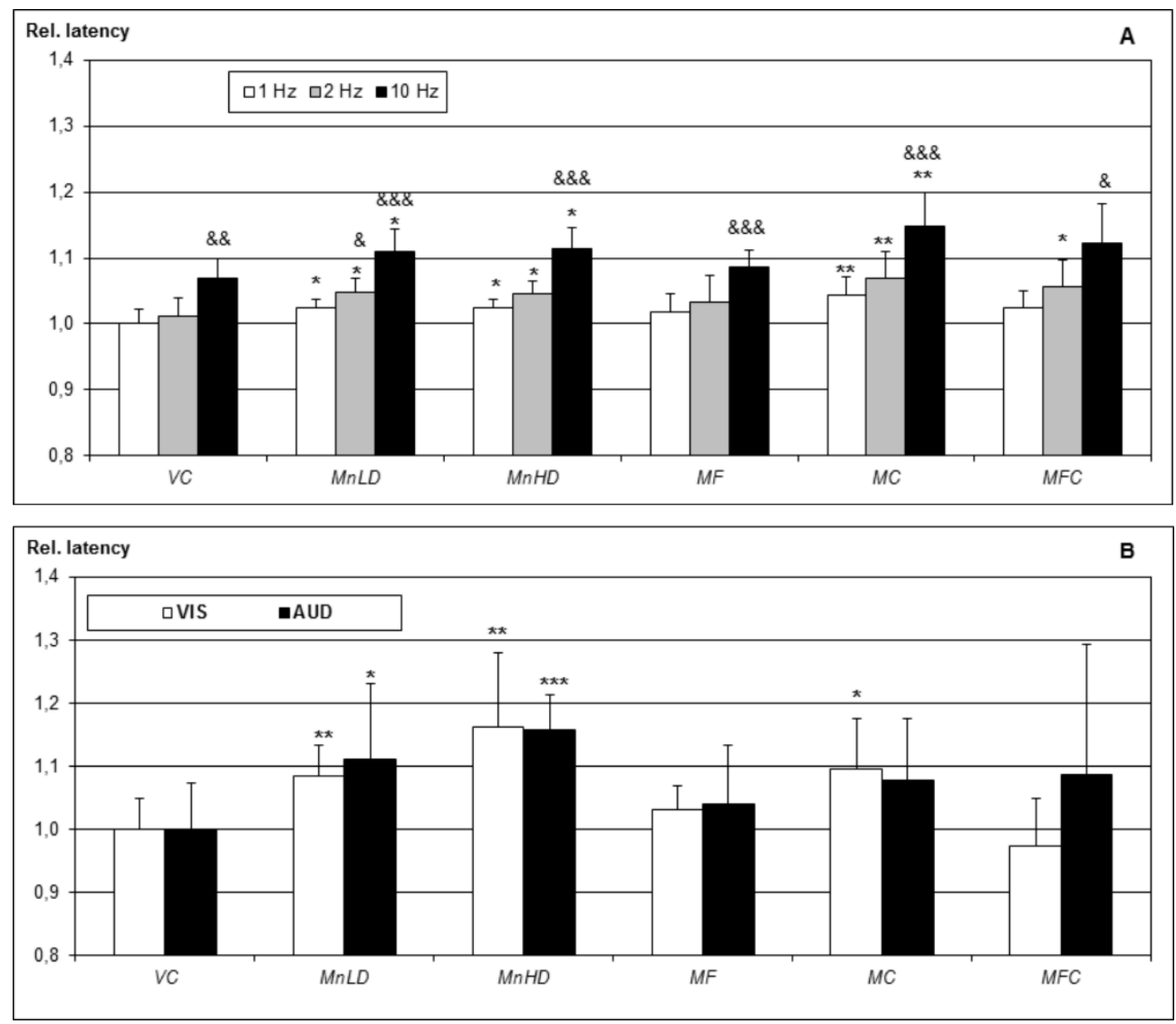

\section{Figure 7.}

Latency of the SS (A), and VIS and AUD (B) cortical evoked potentials. Relative values, normalized to the latency in group $V C$ (for the somatosensory EPs, to the latency obtained with $1 \mathrm{~Hz}$ stimulation, see insert in A). This figure shows latency data in relative values, normalized to the latency of the SS EP obtained with $1 \mathrm{~Hz}$ stimulation in the $V C$ group. Data of the untreated control (Cont) are not displayed because the difference between Cont and $V C$ was negligible.

Mean+SD, $\mathrm{n}=8 . * * *, * * *: \mathrm{p}<0.05,0.01,0.001$ vs. $V C$ (for the SS EPs, at identical stimulation frequency). \&, \&\&, \&\&\&: for SS EPs, p < 0.05, 0.01, $0.001 \mathrm{vs.} 1 \mathrm{~Hz}$ stimulation within the same group. 


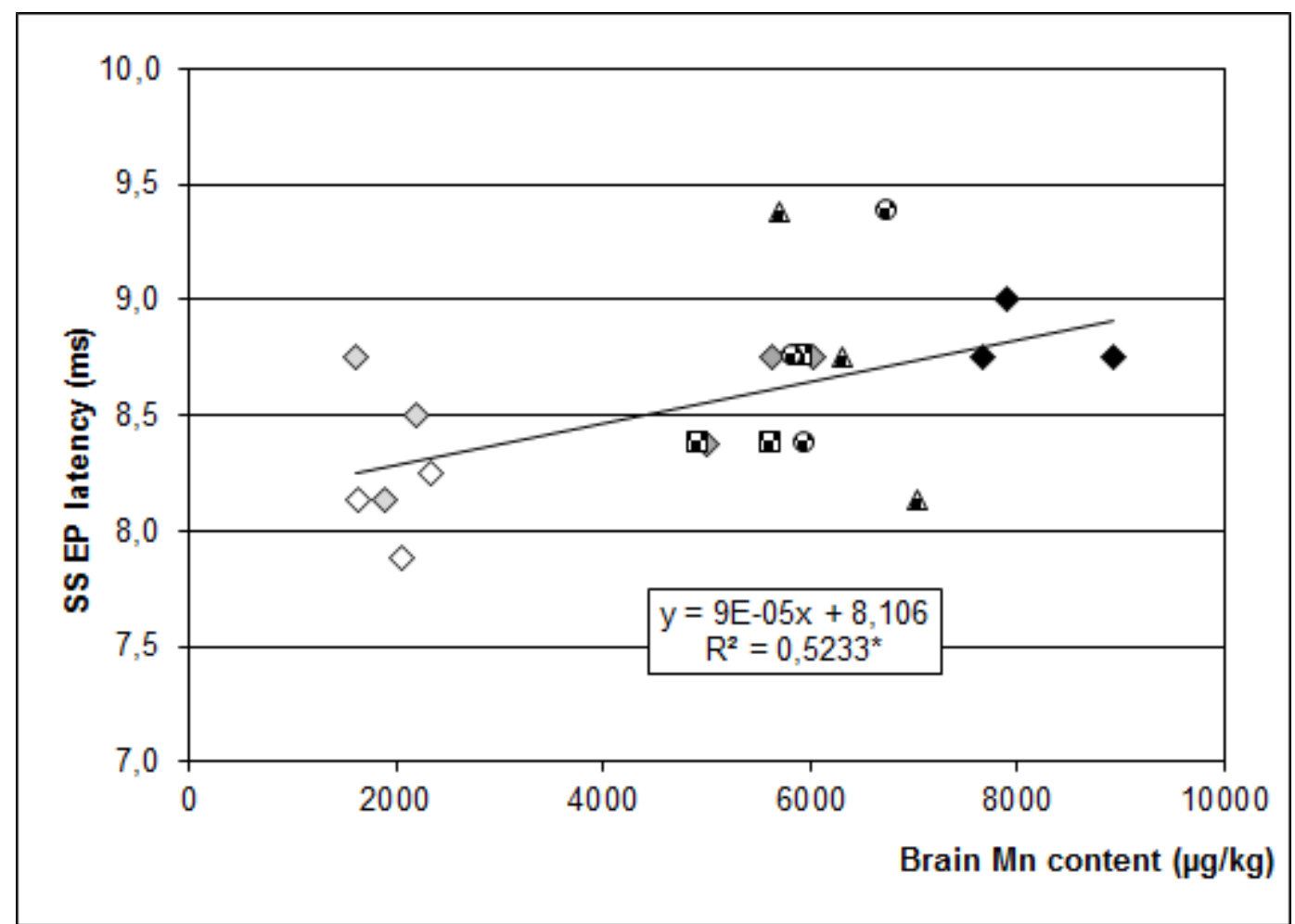

\section{Figure 8.}

Correlation of the latency of the SS EPs (ordinate) to brain Mn levels (abscissa).

Each point represents a data pair from an individual rat chosen for metal level measurement (see Methods). Light symbols, Cont; light grey symbols, $V C$; dark grey symbols, $M n L D$; black symbols, $M n H D$. Patterned symbols indicate combinations of NPs: squares, $M F$; circles, $M C$; triangles, $M F C$. Inserts: equation and $\mathrm{R}^{2} ; *: \mathrm{p}<0.05$ (F-test for the linear fit). 